Pleione 14(2): 337 - 342. 2020.

(C) East Himalayan Society for Spermatophyte Taxonomy

doi:10.26679/Pleione.14.2.2020.337-342

\title{
Lectotypification of two names in the genus Schizachyrium Nees (Poaceae: Andropogoneae)
}

\author{
Shailja Tripathi ${ }^{1,2}$, Dileshwar Prasad ${ }^{1}$, Rekha Yadav ${ }^{1}$, Shubham Jaiswal ${ }^{1}$, Gauri \\ Saxena ${ }^{2}$ and Priyanka Agnihotri ${ }^{1,3}$
}

${ }^{1}$ Plant Diversity, Systematics \& Herbarium Division, CSIR-National Botanical Research Institute, Rana Pratap Marg, Lucknow, 226001, India

${ }^{2}$ Department of Botany, University of Lucknow, Lucknow, 226007, India

${ }^{3}$ Corresponding author, e-mail: priyagni_2006@yahoo.co.in

[Received 07.12.2020; Revised 18.12.2020; Accepted 22.12.2020; Published 31.12.2020]

\begin{abstract}
While revising the tribe Andropogoneae (Poaceae) from Western Himalaya, two names in the genus Schizachyrium viz. S. exile (Hochstetter) Pilger and S. delavayi (Hackel) Bor for which lectotypes had not been designated, are lectotypified here.
\end{abstract}

Key words: Lectotype, Poaceae, Schizachyrium exile, Schizachyrium delavayi

\section{INTRODUCTION}

Schizachyrium Nees, a cosmopolitan genus, nested in the tribe Andropogoneae Dumort. of Poaceae Barnhart comprises ca. 64 species mainly distributed in tropics and temperate regions of the world (Kellogg 2015; Soreng et al. 2017). The genus includes caespitose, perennial or annual herbs with membranous ligule, unbranched inflorescences and clavate internodes (Kellogg 2015). Species of Schizachyrium are characterized by having solitary racemes supported by spathes at the end of culms and branches. Recent phylogenetic studies indicate that Schizachyrium may be of monophyletic origin and sister to Andropogon L. (Estep et al. 2014). Occurrence of unbranched inflorescences in Schizachyrium distinguishes it from Andropogon where paired or digitate branches in the inflorescence are present. In India, the genus is represented by five species viz. S. brevifolium (Swartz) Nees ex Buse, S. delavayi (Hackel) Bor, S. exile (Hochstetter) Pilger, S. impressum (Hackel) A. Camus and S. sanguineum (Retzius) Alston chiefly distributed in Western Himalaya, Northeast India and Western Ghats. Western Himalaya harbours three species of Schizachyrium including S. brevifolium, S. exile and S. impressum (Tripathi et al. 2019) whereas S. brevifolium and S. exile have also been reported from Western Ghats (Sreekumar \& Nair 1991; Potdar et al. 2012). S. delavayi and S. sanguineum inhabit the north eastern region of the country (Shukla 1996). During revisionary studies in the tribe Andropogoneae from Western Himalaya, perusal of literature revealed that $S$. exile and $S$. delavayi remain surrounded by uncertainty in typification. Numbered collections cited in the protologue indicated a gathering of several specimens. Rigorous survey of literature and critical examination of the specimens housed in different herbaria evinced the need to lectotypify these names under the Article 9.3 of the ICNafp (Turland et al. 2018).

\section{MATERIALS AND METHODS}

The present study is based on the survey of the relevant literature and examination of the specimens kept in the following herbaria (acronyms according to Thiers 2020): G, GH, GOET, $\mathrm{K}, \mathrm{L}, \mathrm{M}, \mathrm{MO}, \mathrm{P}, \mathrm{S}, \mathrm{TUB}$ and $\mathrm{W}$. The digital images of the authentic specimens from the above 
mentioned herbaria were procured from their websites. For the selection of types, protologues have been compared with original material and the most complete and informative specimens were selected (Art. 9.3 of the ICNafp, Turland et al. 2018).

\section{TYPIFICATION}

Schizachyrium exile (Hochstetter) Pilger, Bot. Jahrb. Syst. 54 (4): 284.1917.

Basionym: Andropogon exilis Hochstetter Flora 27: 241. 1844.

Lectotype (designated here): [SUDAN, Kordofan, Jebel Arashkol] ("Cordofani AraschCool"), 1839, Kotschy 370 (TUB007032 [digital image!]) (Figure 1). Isolectotypes: W18890263642 [digital image!], K000280384 [digital image!], P00440402 [digital image!], GH00056770 [digital image!].

Further original materials traced:-[SUDAN, Kordofan], 1837, Kotschy 19 (B100167219 [digital image!]), (G00022660 [digital image!]), (GOET006919 [digital image!]), (HOH009134 [digital image!]), (K000280381 [digital image!]), (L0050064 [digital image!]), (M0103825 [digital image!]), (MO-1660973 [digital image!]), (P00440403 [digital image!]), (S10- 22175 [digital image!]), (TUB007031 [digital image!]).

Hochstetter (1844) in the protologue, indicated the basis of new species as "In pll. exsicc. un. itin. ex Kotscbyi it. Nubico nr. 370. et in Kotschyi Flora aethiopia exsicc. nr. 19" from the east side of "montis Cordofani Arasch- Cool" (apparently Jebel Arashkol in the Kordofan region of Sudan) without specifying any herbarium in which the original material was preserved. We traced digital images from online repositories of original material and found sixteen sheets bearing two collection numbers, of which two each are housed in K, P and TUB and one each in $\mathrm{B}, \mathrm{G}, \mathrm{GH}, \mathrm{GOET}, \mathrm{HOH}, \mathrm{L}, \mathrm{M}, \mathrm{MO}, \mathrm{S}$ and $\mathrm{W}$ which are in accordance with the citations in the protologue. Among the competing original material, the specimen with the collection no. 370 deposited at TUB (Figure 1) which best matches with the protologue is selected here as the lectotype of the name Schizachyrium exile (Hochstetter) Pilger.

Note: Schizachyrium exile (Hochstetter) Pilger was originally described as Andropogon exilis by Hochstetter (1844) in 'Flora oder Allgemeine Botanische Zeitung' based on the collection of Kotschy from Kordofan region of Sudan. Later on, Pilger (1917) transferred the specific epithet of Hochst's Andropogon exilis to the genus Schizachyrium forming a new combination viz. Schizachyrium exile (Hochstetter) Pilger.

Schizachyrium delavayi (Hackel) Bor, Indian Forest Rec., Bot. 1(3): 95. 1938.

Basionym: Andropogon delavayi Hackel, A. Candolle \& C. Candolle, Monogr. Phan. 6: 404. 1889.

Lectotype (designated here): CHINA. Yunnan, near Hoken, 19 November 1886, P.J.M. Delavay 1800 [W 19160027418 (digital image!)] [Figure 2].

Further original material traced: Yunnan, [Dali], 6 May 1887, P.J.M. Delavay 2242 [W19160027417 (digital image!)].

Andropogon delavayi was described by Hackel (1889: 404) in 'Monographiae phanerogamarum', where he mentioned two specimens. He wrote of the source of the species: "China australis, prov. Yun-nan : Kimi-se ad pedes Hee-schan-men prope Hoken (Delavay 1800 in h. paris.) ; in pratis ad Ki-pin-Kay prope Tali (id. n. 2242)." We could trace two sheets of $A$. delavayi of the herbarium P preserved at the herbarium W. Among the competing material, the specimen with the best representative material under collection number 1800 (Figure 2) is designated here as the lectotype (Article 9.3, ICN, Turland et al. 2018). 
Shailja Tripathi et al. 339

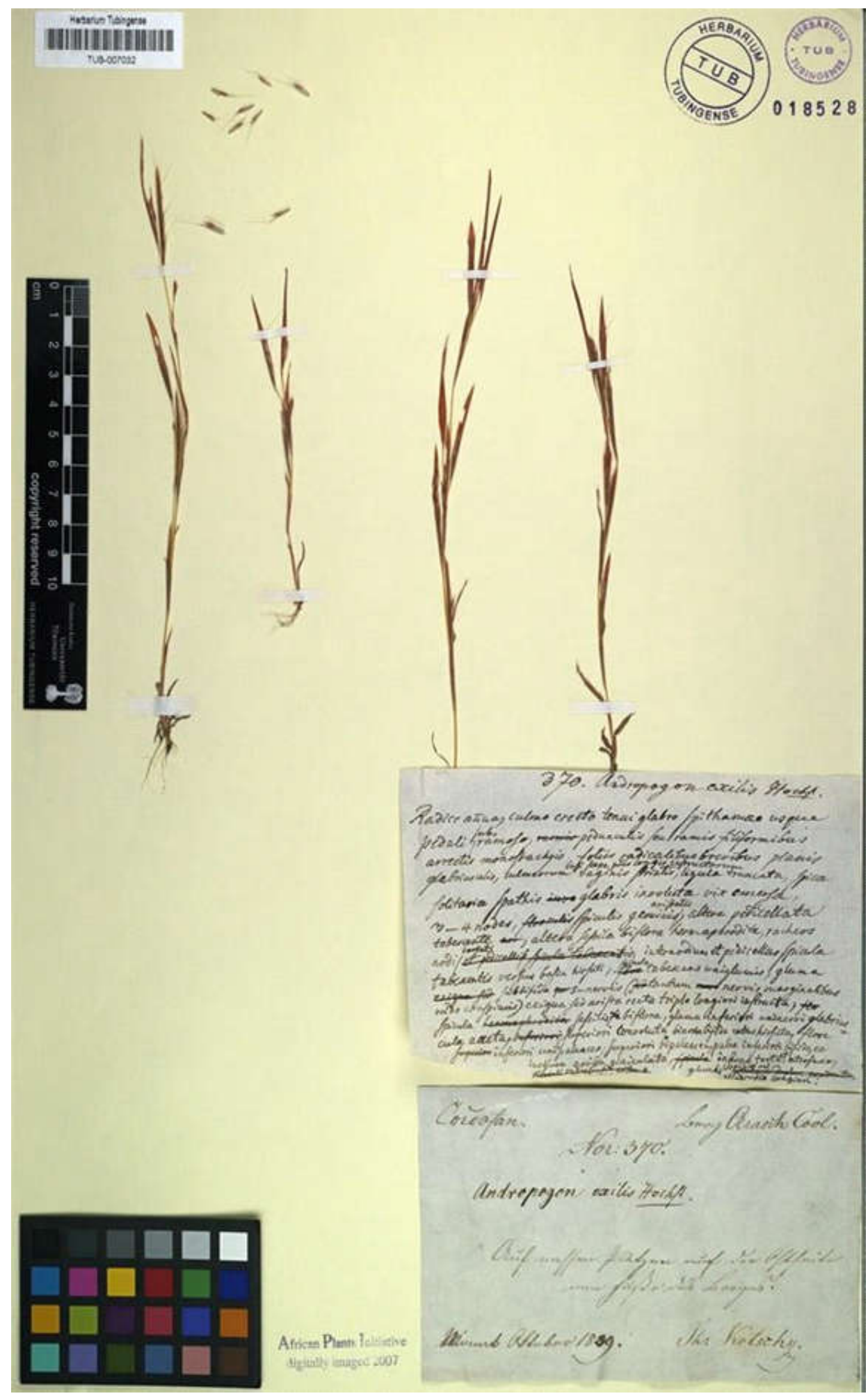

Figure 1. Lectotype image of Schizachyrium exile (Hochst.) Pilg. [@: Director, TUB] 


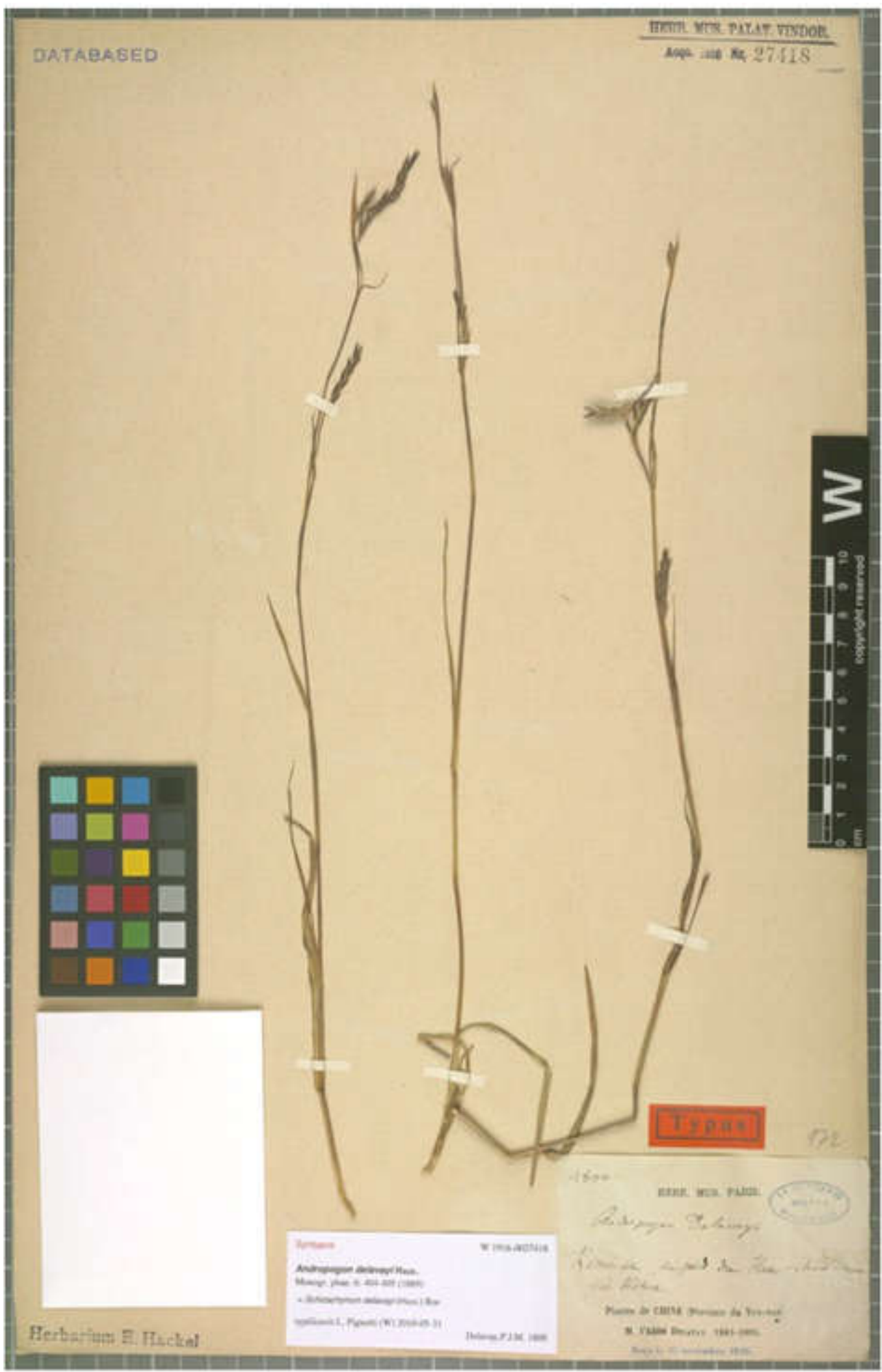

Figure 2. Lectotype image of Schizachyrium delavayi (Hack.) Bor. [@: Director, W] 
Note: Schizachyrium delavayi (Hackel) Bor was originally described as Andropogon delavayi by Hackel (1889) in 'Monographiae Phanerogamarum' based on the collections of Delavay from Yunan. As revealed from the available literature, Delavay's type specimens are preserved at P (Stafleu \& Cowan 1976) while Hackel's at W (Stafleu \& Cowan 1979). So, we could infer that the specimens collected by Delavay preserved at $\mathrm{P}$ might have been transferred to $\mathrm{W}$ in any way, where Hackel had described Andropogon delavayi. Later on, Bor (1938) transferred the specific epithet of Hackel's Andropogon delavayi to the genus Schizachyrium forming a new combination viz. Schizachyrium delavayi (Hackel) Bor.

\section{Acknowledgements}

We acknowledge the Director, CSIR- National Botanical Research Institute, Lucknow for providing us the necessary facilities. We also thank Dr. Tariq Husain, Former Senior Principal Scientist, CSIR- National Botanical Research Institute, Lucknow for his consistent guidance. We are thankful to the Curators of G, GH, GOET, K, L, M, MO, P, S, TUB and W for providing access to the herbarium specimens online. Grant support in the form of fellowship to ST, DP and RY from CSIR, New Delhi is thankfully acknowledged. SJ is thankful to the UGC, New Delhi for providing the research funding.

\section{LITERATURE CITED}

Bor, N.L. 1938. A list of the grasses of Assam. Indian For. Rec. n.s. Bot. 1 (3): 47 " 102. Estep, M.C.; McKain M.R.; Vela Diaz, D.; Zhong, J.; Hodge, J.D.; Hodkinson, T.R.; Layton,D.J.; Malcomber, S.T.; Pasquet, R. \& Kellogg, E.A. 2014. Allopolyploidy,diversification, and the Miocene grassland expansion. Proceedings of the National Academy of Sciences 111: 15149 “ 15154.

Hackel, E. 1889. Andropogoneae. In: Candolle, A.L.P.P. \& Candolle, A.C.P. (eds.),Monographiae Phanerogamarum, 6: 1 - 716. Sumptibus G. Masson, Paris.

Hochstetter, C.F.F. 1844. Gramina nova Africana. Flora 27: 24 -254.

Kellogg, E.A. 2015. Poaceae. In: Kubitski, K. (ed.), The families and genera of vascularplants, 13: 1 “416. Springer, Berlin.

Pilger, R.K.F. 1917. Gramineae africanae (Andropogoneae). Botanische Jabrbücherfür Systematik, Pflanzengeschichte und Pflanzengeographie 54: 279 - 288.

Potdar, G.G.; Salunkhe, C.B. \& Yadav, S.R. 2012. Grasses of Maharashtra. Shivaji University, Kohlapur.

Shukla, U. 1996. The Grasses of North-Eastern India. Scientific Publishers, Jodhpur.

Soreng, R.J.; Peterson, P.M.; Romaschenko, K.; Davidse, G.; Teisher, J.K.; Clark, L.G.; Barberá, P.; Gillespie, L.J. \& Zuloaga, F.O. 2017. A worldwide phylogenetic classification of the Poaceae (Gramineae) II: An update and a comparison of two 2015 classifications. J. Syst. Evol. 55: 259 - 290.

Sreekumar, P.V. \& Nair, V.J. 1991. Flora of Kerala- Grasses. Botanical Survey of India, Calcutta.

Stafleu, F.A. \& Cowan, R.S. 1976. Taxonomic literature. A selective guide to botanica publications and collections with dates, commentaries and types. $2^{\text {nd }}$ Edition,1: $1-1136$. Bohn, Scheltema \& Holkema, Utrecht.

Stafleu, F.A. \& Cowan, R.S. 1979. Taxonomic literature. A selective guide to botanica publications and collections with dates, commentaries and types, $2^{\text {nd }}$ Edition, 2: 1 - 991. Bohn, Scheltema \& Holkema, Utrecht. 
Thiers, B. 2018. Index Herbariorum: A global directory of public herbaria and associated staff. New York Botanical Garden's Virtual Herbarium. Available from: http:// sweetgum.nybg.org/science/ih/ (accessed 10 June 2020).

Tripathi, S.; Agnihotri P.; Yadav R.; Prasad D.; Jaiswal S. \& Husain T. 2019. A conspectus of the tribe Andropogoneae in Western Himalaya. Pleione. 13(1): 90 “ 102.

Turland, N.J.; Wiersema, J.H.; Barrie, F.R.; Greuter, W.; Haksworth, D.L.; Herendeen, P.S.; Knapp, S.; Kusber, W.-H.; Li, D.-Z.; Marhold, K.; May, T.W.; McNeill, J.; Monro, A.M.; Prado, J.; Price, M.J. \& Smith, G.F. (eds.) 2018: International Code of Nomenclature for algae, fungi, and plants (Shenzhen Code) adopted by the Nineteenth International Botanical Congress Shenzhen, China, July 2017. Regnum Vegetabile 159. Koeltz Botanical Books, Glashütten: 351 pp. https://doi.org/10.12705/Code. 2018. 